\title{
The Relationship between Teacher Autonomy Support and the Attitude and Anxiety toward Mathematics Course
}

\author{
Cengiz Erdik ${ }^{1}$ \\ ${ }^{1}$ Enstitues of Education Science, Near East University, Cyprus \\ Correspondence: Cengiz Erdik, Enstitues of Education Science, Near East University, Cyprus. E-mail: \\ erdikcengiz@gmail.com
}

Received: January 17, 2018

Accepted: March 4, 2018 Online Published: May 29, 2018

doi:10.5539/ies.v11n6p109

URL: https://doi.org/10.5539/ies.v11n6p109

\begin{abstract}
The purpose of the present research is to determine the correlation between attitude and anxiety of seventh and eighth grade students toward mathematics course and behaviors of mathematics teachers to support and exhibit learner autonomy toward mathematics course. The population of the research was consisted of 1.563 students and 35 mathematics teachers from 22 schools. Research data was collected by means of Learner Autonomy Support Scale and Mathematics Course Attitude and Anxiety Scale. Conclusively, it was revealed that eighth grade students were more anxious, their anxiety levels and attitudes differed according to their success levels, and that they did not exhibit statistically significant difference according to their genders and teachers' genders. It was determined that there is no statistically significant correlation between level of teachers' support for learner autonomy and students' anxiety and attitude levels toward mathematics course.
\end{abstract}

Keywords: anxiety, attitude, mathematics, autonomy support

\section{Introduction}

Mathematics, taught to students along their education life and beyond, has significant contribution in development of scientific life, and it is essential for human life. Through math education, individuals gain mathematical knowledge and skills necessitated by daily life, learn way of problem solving, and gain a philosophy to assess incidents in problem solving approach (Altun, 2005). Math has significant place in education life due to its unique structure, content and system. Although it is an evident fact, many of us would not be aware of positive impact of math on function and development of our brain (Üldaş, 2005).

Turkish students display poor performance in math exams at domestic and international scales. Whereas Turkey is ranked as 30th in the TIMSS in 2007, 4th and 8th grade students were ranked as 35th and 24th in 2011, respectively (Yücel, Karadağ, \& Turan, 2013). In terms of the SBS Exam held across Turkey, students displayed the lowest success with the math course based on their average scores of 3.19 and 4.39 in 2011 and 2012, respectively (MNE, $2011 ; 2012)$. There are numbers of factors effective on success in math. Students' anxiety and attitude toward math are considered among these factors. Math is perceived as a difficult course by many students; thus, their attitude toward math is usually negative. They feel anxious about math because they worry about their success at math (Baykul, 1999). Based on the researches in the relevant literature, it was observed that there is positive correlation between attitude toward math and success level (Katranc1, 2009; Tapia \& Marsh, 2000; Yenilmez \& Özabac1, 2003; Yücel \& Koç, 2011). There is strong correlation between anxiety and academic success level of student. Anxiety is discrepancy status experienced by students when they face with a stimulus that is exposed symptoms such as sentimental, physical and mental changes. Individuals experiencing intensive anxiety not only face some physical stimulation, but as well they feel anxious about their performances (Taş, 2009). With regard to anxiety felt toward math, this status is described as emotional stress or concern felt when experienced with difficulties at school or in daily life such as math problems and four operations (Tobias, 1993). Majority of students avoid math operations because they fear making mistakes. Studies conducted on math fear and associated anxiety has revealed that as students get experienced with math, their positive attitude toward math decreases (Altun, 2005). Negative experiences related with math, lack of sufficient parental support, negative attitude toward math, lack of self-confidence and respect, negative classroom atmosphere and inappropriate learning methods serving learning purposes could result in anxiety about math (Ma, 1999). That is, math anxiety and attitude toward math mutually affect one another. 
Math anxiety among students is effective on their success at math course (Thomas \& Higbee, 1999; Yenilmez \& Özabac1, 2003; Yenilmez \& Özbey, 2006). A negative correlation was reported between math anxiety and success (Ma \& Xu, 2004). Moreover, according to the studies on math instruction, math anxiety has negative influence on learning processes (McLeod, 1988; Sloan, Daane, \& Geisen, 2002; Vinson, 2001), and this a situation is frequently experienced by educators (Bursal \& Paznokas, 2006; Reys, 1995; Zettle \& Raines, 2000).

In researches conducted on individuals with anxiety toward mathematics, it was determined that these people establish connections between their negative experiences and their former math teachers (Frank, 1990). As math teachers allow students to make their own decisions in learning activities and to let them feel authentic, students would develop positive attitude toward math. From this point of view, attitude adopted by teachers toward their students, their teaching approach within classroom and created classroom atmosphere are effective on attitudes of students toward math (Ekizoğlu \& Tezer 2007). Instead of oppressive and restricting attitude, teachers' behavior supporting autonomy would be effective in moderating students' anxiety and in developing positive attitude toward math. Studies from the relevant literature revealed that teachers' behaviors supporting students' autonomy is one of the essential variables effective on students' attitudes and anxiety toward math, and that students perceive motivational support from their teachers in way that it reduces boredom and disappointment felt during class (Skinner et al., 2008), and perceive excessive teacher control as a factor to increase their anxiety toward the course. On the other hand, Yildırım (2000) reported that support given to students from teachers and their parents increase success of students in Math, Turkish, Physics, Chemistry and Biology courses. Nevertheless, loneliness and anxiety have negative significant influence. Similarly, Yıldırım and Ergene (2003) reported that teacher support given to to 11th grade students is effective on their anxiety significantly and negatively.

Teachers are of the opinion that autonomy support must be given to students, however, they do not exhibit this (Oğuz, 2013; Özkal \& Demirkol 2014). There are researches in the relevant literature, which determined that autonomy support of primary education math teachers is at medium level (Güvenç \& Güvenç, 2014), and that among teachers from primary and secondary schools, math teachers exhibit the lowest level of learner autonomy support in general (Özkal \& Demirkol, 2014).

In the present study, it was aimed to determine the correlation between mathematics teachers' support for autonomy and students' attitude and anxiety toward math. Accordingly, we tried to answer following questions:

1) Do students' anxiety and attitudes toward math exhibit significant difference according to gender of both themselves and their teachers, their grade and their success levels?

2) What do teachers think about supporting and exhibiting learner autonomy?

\section{Method}

This section includes the research model, the research process, the participants, data collection and analysis processes.

\subsection{Research Model}

In the present research, relational survey model which investigates existence of mutual change and/or its degree between two or more variables was utilized (Karasar, 2009).

\subsection{Participants}

This research was conducted based on volunteer participation of 1.563 seventh and eighth grade students and 35 mathematics teachers from 22 middle schools in Alanya County of Antalya City during 2014-2015 academic year upon issuance of permission for survey application. $1.4 \%$ of participant students were female $(\mathrm{n}=803), 48.6 \%$ were male $(n=760) .51 .4 \%$ of students were from seventh grade $(n=804), 48.6 \%$ were from the eighth grade $(n=759)$. Finally, $68.6 \%$ of teachers were female $(\mathrm{n}=24), 31.4 \%$ were male $(\mathrm{n}=11)$.

\subsection{Data Collection Tools}

The research data was collected from students through the Math Anxiety Scale (Bindak, 2005) and the Attitude Scale towards Math Course, and from teachers through the Teachers' Learner Autonomy Supporting Behavior Scale (Oğuz, 2012). In order to determine students' anxiety towards math, "Mathematics Anxiety Scale" developed by Bindak (2005) for primary school students was utilized. It was determined that this scale whose reliability and validity analyses were conducted by Bindak, was consisted of a single factor which could explain $51.7 \%$ of the total variance. Moreover, reliability coefficient (Cronbach's Alpha) of this scale consisted of 9 positive and 1 negative item was estimated at 0.80 . Total reliability coefficient of the scale was estimated at 0.737 for the Mathematics Anxiety Scale.

In order to determine attitude of students towards math, "Attitude Scale towards Math Course" developed by 
Aşkar (1986) was utilized. This scale was composed of two sub-scales: positive and negative attitudes towards math. Total reliability coefficient of the scale was estimated at 0.96 for this study. Whereas positive attitude towards math sub-scale was determined as 0.906 , the negative attitude towards math sub-scale was determined as 0.879 .

Data regarding necessity and exhibition of behaviors of teachers supporting autonomy of students was collected through "the Scale for Behavior of Teachers Supporting Learners' Autonomy" developed by Oğuz (2012), consisted of two sections. the first section was measuring the level of importance of autonomy-supporting behaviors for students, the second section was determining level of expression of these behaviors to their students. After teachers expressed their opinions regarding the necessity of these behaviors, they were expected to express how strong they exhibit these behaviors. The scale was structured in five-point likert model and consisted of 16 items and 3 factors. Cronbach's Alpha internal consistency coefficient for the general scale was determined for the necessity as $\alpha=0.89$, for the exhibition strength as $\alpha=0.92$. Cronbach's alpha coefficients for emotion and opinion support under the necessity aspect were determined as $\alpha=0.85$, for support in learning process, determined as $\alpha=0.76$, and for evaluation support, determined as $\alpha=0.88$. For emotion and opinion support within the exhibition strength, it was determined as $\alpha=0.88$, for support in learning process, it was determined as $\alpha=0.80$, and for evaluation support, it was determined as $\alpha=0.86$. Goodness fit statistic results obtained through the confirmatory factor analysis indicated that model's goodness of fit was sufficient for "the necessity" based on the estimated AGFI value at 0.89 , GFI value at 0.92 , CFI value at 0.97 and RMSEA value at 0.064 . When model's goodness of fit values were considered for "Exhibition Strength", following values of AGFI, GFI, CFI, RMSEA and SRMR were determined as $0.86,0.90,0.97,0.077$ and 0.052 . This scale was considered as reliable and valid, and thus, it was applied on primary, secondary and high school teachers (Oğuz, 2012).

\section{Results}

As can be seen in Table 1, t-test was conducted to determine whether there is significant difference between students' anxiety and attitude levels according to their gender. As a result of the analysis, it was determined that there was no significant difference between students' anxiety levels according to their genders ( $\mathrm{t}=-.335$, $\mathrm{p}=.73>.05)$, and their positive attitudes $(\mathrm{t}=.834, \mathrm{p}=.405>.05)$ and negative attitudes $(\mathrm{t}=-.666, \mathrm{p}=.50>.05)$ were not significantly different.

Table 1. Levels of students' anxiety and attitude towards math according to their gender

\begin{tabular}{cccccc}
\hline Variable & Students' Gender & $\bar{X}$ & $\mathrm{SS}$ & $\mathrm{t}$ & $\mathrm{p}$ \\
\hline \multirow{2}{*}{ Anxiety } & Female & 2.61 & .82 & & \\
& Male & 2.63 & .80 & -.335 & .73 \\
Positive attitude & Female & 3.13 & 1.06 & & \\
& Male & 3.09 & 1.03 & .834 & .40 \\
Negative attitude & Female & 2.56 & .83 & & \\
& Male & 2.59 & .77 & -.666 & .50 \\
\hline
\end{tabular}

Table 2. Levels of students' anxiety and attitude towards math according to the gender of math teachers

\begin{tabular}{cccccc}
\hline Variable & Teachers' Gender & $\bar{X}$ & $\mathrm{SS}$ & $\mathrm{t}$ & $\mathrm{p}$ \\
\hline \multirow{2}{*}{ Anxiety } & Female & 2.64 & .83 & \multirow{2}{*}{1.05} & .29 \\
& Male & 2.59 & .78 & & \\
Positive attitude & Female & 3.09 & 1.04 & \multirow{2}{*}{1.05} & .29 \\
& Male & 3.15 & 1.04 & & \\
Negative attitude & Female & 2.59 & .81 & \multirow{2}{*}{1.09} & .27 \\
& Male & 2.54 & .79 & & \\
\hline
\end{tabular}

As can be seen in Table 2, t-test was conducted to determine whether there was significant difference between students' anxiety and attitude levels towards the course according to gender of math teachers.

As a result of the analysis, it was determined that there was no significant difference among students' anxiety levels $(\mathrm{t}=1.05, \mathrm{p}=.293>.05)$, their positive attitudes $(\mathrm{t}=-1.05, \mathrm{p}=.290>.05)$ and negative attitudes $(\mathrm{t}=1.09$, $\mathrm{p}=.273>.05$ ) according to gender of teachers. 
Table 3. Levels of students' anxiety and attitude towards math according to their grades

\begin{tabular}{cccccc}
\hline Variable & Grade & $\bar{X}$ & $\mathrm{SS}$ & $\mathrm{t}$ & $\mathrm{p}$ \\
\hline \multirow{2}{*}{ Anxiety } & 7 & 2.57 & .79 & & \\
& 8 & 2.67 & .83 & -2.58 & .01 \\
Positive attitude & 7 & 3.14 & 1.03 & & \\
& 8 & 3.07 & 1.05 & 1.36 & .17 \\
Negative attitude & 7 & 2.57 & .80 & & \\
& 8 & 2.57 & .80 & .05 & .95 \\
\hline
\end{tabular}

As can be seen in Table 3, t-test was conducted to determine whether there is significant difference between students' anxiety and attitude levels towards the math according to students' grades. As a result of the study, while a significant difference was found between students' anxiety levels with respect to their grades $(\mathrm{t}=-2.58$, $\mathrm{p}=.010<.05)$, no any significant difference was determined between their positive attitudes $(t=-1.36, \mathrm{p}=.171>.05)$ and between their negative attitudes $(\mathrm{t}=.056, \mathrm{p}=.95>.05)$. Accordingly, anxiety level of the seventh grade students ( $\bar{X}=2.57)$ was lower in comparison with the eighth grade students $(\bar{X}=2.67)$.

Table 4. Variance analysis results regarding students' success in math course, levels of their anxiety and attitude towards math

\begin{tabular}{lcccccc}
\hline Variables & $\begin{array}{c}\text { Math scores } \\
\text { in reports }\end{array}$ & $\mathrm{n}$ & $\bar{X}$ & $\mathrm{SS}$ & $\mathrm{F}$ & $\mathrm{P}$ \\
\hline \multirow{4}{*}{ Anxiety } & 1 & 124 & 3.3 & .74 & & \\
& 2 & 256 & 3.1 & .70 & & \\
& 3 & 447 & 2.7 & .70 & 163.6 & .000 \\
& 4 & 390 & 2.4 & .70 & & \\
Positive attitude & 5 & 343 & 1.9 & .59 & & \\
& 1 & 124 & 2.60 & 1.06 & & \\
& 2 & 256 & 2.70 & .96 & & \\
& 3 & 447 & 2.90 & .93 & 65.5 & .000 \\
Negative attitude & 4 & 387 & 3.18 & .93 & & \\
& 5 & 342 & 3.77 & 1.01 & & \\
& 1 & 122 & 2.85 & .84 & & \\
& 2 & 257 & 2.82 & .76 & & \\
& 3 & 448 & 2.74 & .75 & 50.9 & .000 \\
& 4 & 388 & 2.54 & .76 & & \\
& 5 & 341 & 2.09 & .73 & & \\
\hline
\end{tabular}

As can be seen in Table 4, variance analysis was conducted to determine whether there was significant difference between levels of students' anxiety and attitude towards the math according to students' success levels in math. As a result of the analysis, it was determined that students' anxiety levels $(\mathrm{F}=163.6, \mathrm{p}=.000<.05)$ exhibited significant difference according to positive $(\mathrm{F}=65.5, \mathrm{p}=.000<.05)$ and negative attitude $(\mathrm{F}=50.9, \mathrm{p}=.000<.05)$ levels. While anxiety level of students whose math scores in their report were $1(\bar{X}=3.30)$ and $2(\bar{X}=2.15)$ was determined as about medium level, anxiety level of the ones with math score of $3(\bar{X}=2.77)$ was higher with respect to the students with math score of $4(\bar{X}=2.48)$ and $5(\bar{X}=1.93)$. Although anxiety level of students with math score of 3 $(\bar{X}=2.77)$ in their report was lower, it was still greater than the anxiety level of students with scores of $4(\bar{X}=2.48)$ and $5(\bar{X}=1.93)$. Although anxiety levels of students with math score of $4(\bar{X}=2.48)$ was determined low, it was still greater than the students with score of $5(\bar{X}=1.93)$. Accordingly, it was concluded that there was negative correlation between students' success levels in math and their anxiety levels.

Accordingly, positive attitude levels of students with math report scores $1(\bar{X}=2.60)$ and $2(\bar{X}=2.70)$ were less than the students whose report score were $3(\bar{X}=2.90), 4(\bar{X}=3.18)$ and $5(\bar{X}=3.77)$. Attitude of students with math report score $3(\bar{X}=2.90)$ were more negative with respect to the students with report scores of $4(\bar{X}=3.18)$ and $5(\bar{X}=3.77)$, attitude of students with report score of $4(\bar{X}=3.18)$ was more negative with respect to the students with report score of $5(\bar{X}=3.77)$. Negative attitude level of students with math report scores of 4 ( $\bar{X}$ $=2.54)$ and $5(\bar{X}=2.09)$ was lower with respect to the students with math report scores of $1(\bar{X}=2.85), 2(\bar{X}$ $=2.82)$ and $3(\bar{X}=2.74)$. Although attitudes of students with math report score of $4(\bar{X}=2.54)$ towards math was 
positive, this level was lower with respect to the students with report score of $5(\bar{X}=2.09)$. Conclusively, it could be stated that as students' math report scores increase, their attitudes towards math differ from negative to positive.

Table 5 includes comparison of answers given by teachers for the questions regarding teachers' belief in necessity of behaviors supporting for learner autonomy and belief in necessity of exhibition of this behaviors. The aspect agreed by teachers in terms of both necessity $(\bar{X}=4.47)$ and exhibition $(\bar{X}=3.97)$ and which has the highest mean was the support for emotion and opinion. The aspect with lowest mean was the support for evaluation (necessity $\bar{X}=4.07$, exhibition $\bar{X}=3.49$ ).

Table 5. Teachers' opinions regarding behaviors for supporting learner autonomy and exhibiting this support

\begin{tabular}{|c|c|c|}
\hline $\begin{array}{l}\text { Necessity } \\
\bar{X}\end{array}$ & $\begin{array}{l}\text { Theorem } \\
\text { Teachers' behavior for supporting learner autonomy }\end{array}$ & $\begin{array}{l}\text { Exhibiting } \\
\qquad \bar{X}\end{array}$ \\
\hline 4.47 & Support for emotion and opinion & 3.97 \\
\hline 4.42 & Approaching students through an empathetically launder standing (putting themselves in students' shoes). & 3.82 \\
\hline 4.57 & Providing opportunity to students to express learning issues. & 4.11 \\
\hline 3.85 & $\begin{array}{l}\text { Sharing emotions and opinions of students regarding all sorts of preferences in learning process (e.g. activity, } \\
\text { material, method and etc.) }\end{array}$ & 3.34 \\
\hline 4.48 & Sharing emotions and opinions of students regarding their learning process. & 4.05 \\
\hline 4.53 & Incenting students to perform additional studies to develop their learning (research, reading, project etc.). & 3.97 \\
\hline 4.68 & Giving feedback to students regarding their learning process. & 4.05 \\
\hline 4.77 & Encouraging students to ask questions. & 4.42 \\
\hline 4.14 & Support for Learning Process & 3.51 \\
\hline 4.11 & Incenting students to use real-life materials (authentic) except grade to use on their own & 3.42 \\
\hline 4.00 & $\begin{array}{l}\text { In order to support students' learning process, ensuring them to receive assistance from persons outside the } \\
\text { classroom (parents, specialist etc.). }\end{array}$ & 3.34 \\
\hline 4.23 & $\begin{array}{l}\text { Supporting students to carry out independent studies in the classroom on their own (solving problem, practicing, } \\
\text { repeating, summarizing etc.). }\end{array}$ & 3.51 \\
\hline 4.20 & Cooperating with students' family regarding subjects relevant with learning process. & 3.42 \\
\hline 4.17 & Assisting students in determining their learning targets. & 3.85 \\
\hline 4.07 & Evaluation support. & 3.49 \\
\hline 3.88 & Allowing students to evaluate each other's work & 3.11 \\
\hline 4.34 & Sharing evaluations regarding students' learning acquisitions. & 3.82 \\
\hline 4.08 & Supporting them to participate in decisions regarding measurement and evaluation. & 3.60 \\
\hline 4.00 & Allowing students to evaluate their own works. & 3.42 \\
\hline
\end{tabular}

In Table 6, correlation analysis was conducted to determine relationship among factors obtained within the research scope. In this respect, no any significant correlation was determined between teachers' belief in necessity of supporting learner autonomy plus their consideration about exhibiting these supportive behavior and students' anxiety and attitudes towards math. 
Table 6. Pearson correlation results

\begin{tabular}{llllllllll}
\hline Factors & 1 & 2 & 3 & 4 & 5 & 6 & 7 & 8 & 9 \\
\hline 1.KYG & 1 & & & & & & & & \\
2.OLT & $-.51^{* *}$ & 1 & & & & & & & \\
3.OMT & $.48^{* *}$ & $-.61^{* *}$ & 1 & & & & & & \\
4.DDDS & -.06 & -.05 & .18 & 1 & & & & & \\
5.OSDS & .02 & .16 & .04 & $.55^{* *}$ & 1 & & & & \\
6.DSDS & -.16 & .16 & -.17 & $.53^{* *}$ & $.67^{* *}$ & 1 & & & \\
7.DDDG & -.17 & -.14 & -.07 & $.38^{*}$ & .13 & .19 & 1 & & \\
8.OSDG & -.07 & .05 & -.18 & .03 & .26 & .21 & $.60^{* *}$ & 1 & \\
9.DSDG & -.07 & .25 & -.24 & .13 & $.47^{* *}$ & $.53^{* *}$ & .38 & $.68^{* *}$ & 1 \\
\hline
\end{tabular}

KYG: Anxiety; OLT: Positive Attitude; OMT: Negative Attitude; DDDS: Exhibiting Support for Emotion and Opinion; OSDS: Exhibiting Support for Learning Process; DSDS: Exhibiting Support for Evaluation Process; DDDG: Necessity of Support for Emotion and Opinion; OSDG: Necessity of Support for Learning Process; DDG: Necessity of Support for Evaluation Process $* * \mathrm{p}<.01, * \mathrm{p}<.05$.

It was determined that degree of teachers' behavior for supporting learner autonomy was not influent on anxiety and attitude levels of students towards math. In this study, each teacher was considered individually. Their opinions regarding necessity and exhibition of supporting behavior for learner autonomy were compared with students' anxiety and attitude mean of scores. Within this scope, it was observed that mean of scores of answers given by teachers were not effective on mean of scores of answers given by students. Concerning necessity of supporting behavior for learner autonomy, math anxiety level in the math given by the teacher with the highest mean of score (for emotion and opinion support $\bar{X}=5.00$, for learning process $(\bar{X})=5.00$, for evaluation support $\bar{X}=5.00$ ) was estimated at $\bar{X}=2.80$; the positive attitude level towards math was estimated at $(\bar{X})=2.95$, and the negative attitude level was estimated at $\bar{X}=2.70$. Concerning necessity of supporting behavior for learner autonomy, math anxiety level in the math given by the teacher with the lowest mean score (for emotion and opinion $\operatorname{support}(\bar{X})=3.57$, for learning process $\bar{X}=3.00$, for evaluation support $\bar{X}=3.25$ ) was estimated at $(\bar{X})$ $=2.06$, positive attitude level toward math was estimated at $\bar{X}=3.26$, and the negative attitude level was estimated at $\bar{X}=2.13$. As it could be observed that while there was significant difference among mean scores of teachers, the similar result was not observed with the anxiety and attitude levels of students.

Concerning exhibition of supporting behavior for learner autonomy, math anxiety level in the classroom where math was given by the teacher with the highest mean score (for emotion and opinion support $\bar{X}=4.57$, for learning process $\bar{X}=4.80$, for evaluation support $\bar{X}=4.25$ ) was estimated at $\bar{X}=2.74$, the positive attitude level towards math was estimated at $(\bar{X})=3.28$, and the negative attitude level was estimated at $\bar{X}=2.30$. Concerning exhibition of supporting behavior for learner autonomy, math anxiety level in the classroom where math course given by the teacher with the lowest mean score (for emotion and opinion support $(\bar{X})=3.43$, for learning $\operatorname{process}(\bar{X})=2.40$, for evaluation support $(\bar{X})=2.00$ ) was estimated at $\bar{X}=2.52$, the positive attitude level towards math was estimated at $\bar{X}=3.22$, and the negative attitude level was estimated at $\bar{X}=2.65$. In terms of the level of exhibiting support, while there was significant difference among mean scores of teachers, this difference was not observed among students' mean scores.

\section{Discussion}

As a result of the study, it was determined that anxiety and attitude levels of students towards math were not exhibiting significant difference according to both genders of themselves and their teachers. When the relevant literature was taken into consideration, it was determined from some researches investigating anxiety towards math in terms of gender variable that there was significant difference between female and male students (Betz, 1978; Haynes et al., 2004; Khatoon \& Mahmood, 2010; Karimi \&Vanketesan, 2009; Kumar \& Karimi, 2010). Some of these studies reported that gender variable was not significantly effective on math anxiety (Arikan, 2004; Aydın, 2011; Dursun \& Bindak, 2011; Gierl \& Bisanz, 1995; Lussier, 1996).

In number of studies investigating anxiety of students towards math, especially gender and success variables were emphasized, and the correlation among variables and attitude towards math was tried to be explained. In majority of these studies, it was reported that gender difference was not effective on attitude towards math (Çelik \& Bindak, 2005; Johnson, 2000; Yücel \& Koç, 2011; Ursini \& Sanchez, 2008). On the contrary, there were studies as well, which reported that gender is effective on attitude towards math, and that attitudes of female and male students differ according to math course. Tapia \& Marsh (2000) reported that self-confidence and motivation levels of male 
students towards math are higher with respect to female students. Similarly, it was reported that female students have lower attitude towards math, and they think that their talent for math is not high as much as male students (McGraw, Lubienski, \& Strutchens, 2006; Yenilmez \& Özabac1, 2003). Therefore, it could be concluded that studies oriented on the correlation between attitude and gender failed to illustrate a clear picture of the relationship.

In the present study, it was reported that anxiety and attitude levels of students towards math exhibited significant difference according to their grade levels. Anxiety levels of the 7th grade students were lower compared to the 8th grade students. In some of the studies in the relevant literature in which effect of the grade variable on math anxiety was investigated, it was reported that students' anxiety towards math display significant difference according to the grade variable, and that as their grade levels increase, their math anxiety increases respectively (Birgin et al., 2010). Dursun and Bindak reported a negative medium level of correlation between math anxiety and math success of students from second grade at a primary school. Moreover, it was found that math anxiety of the eighth grade students was significantly higher than the sixth and seventh grade students (Dursun \& Bindak, 2011). However in some studies, it was determined that grade variable was not effective on math anxiety (Dede \& Dursun, 2008).

There are some studies which reported that attitudes of first grade students towards math was rather higher, additionally, that as their grade level increases, their attitudes decreases. Taşdemir (2009), in his study conducted on the 6th, 7th and 8th grade students, observed a reduction in attitude level of students as their grade level decreases. Altun (1995), in his study conducted on third, fourth and fifth grade students, suggested that attitude towards math decreases as their grade level increases. Baykul (1990) reported that attitudes of students towards math and natural science courses continuously and negatively change from the fifth grade in primary school to senior grade levels of high school and its equivalents.

In this study, it was determined that anxiety and attitude levels of students towards math differ significantly according to their success levels. As success levels of students increase, their anxiety levels decrease, and vice versa. In the relevant literature, there are several studies reporting positive correlations between attitude towards math and success in math course (Johnson, 2000; Katranc1, 2009; Tapia \& Marsh, 2000; Yenilmez \& Özabac1, 2003; Yücel \& Koç, 2011). In the relevant literature, there are also studies reporting negative correlation between math success and math anxiety (Ma \& Xu, 2004; Yenilmez \& Özabac1, 2003). Anxiety has significant role in development of positive attitude by students towards math and enhancing their success levels (Peker \& Mirasyedioğlu, 2003).

In the present research, it was determined that among supporting behaviors of teachers for learner autonomy, they mostly think that necessity and exhibition of supporting behavior for emotion and opinion are important. This opinion was followed by behavior for supporting learning process and evaluation. Incenting students to feel free to ask question during classes, providing them opportunity to express their opinions concerning learning issues and sharing their emotions and opinions concerning their learning were the most preferred behaviors adopted by teachers to support learner autonomy. Encouraging students to perform additional studies to enhance what they learnt, approaching them in an emphatically way and assisting them to determine learning targets were the other important behaviors adopted by teachers.

Additionally, teachers were ranked based on their mean scores from low to high related in terms of their belief in necessity of support for learner autonomy and their exhibition level of this behavior. Similarly, answers of students which concern anxiety and attitude given for each teacher were written in the table within the section of the associated teacher. Although teachers were ranked respectively, answers of students did not differ proportionally. Based on these results, it was concluded supporting behaviors of teachers for learner autonomy were not effective on anxiety and attitudes of students towards math. However, there was an important point in here. It was the fact that teachers' behavior to support learner autonomy was not effective on students' anxiety and attitudes could be result of students' misperception of these behaviors.

According to the findings obtained in the study, mean of scores of answers given by teachers concerning necessity of supporting learner autonomy were found higher than mean scores of answers given by teachers concerning exhibiting this behavior. There is need for studies investigating reasons which prevent teachers to exhibit supporting behaviors for learner autonomy in the future. Besides, it is important to apply the scale applied on teachers to determine their supporting behavior for learner autonomy must be applied to students as well so as to compare the relevant means of scores of teachers and students, which enable us to comprehend whether behaviors of teachers exhibited to their students are perceived in the same way with teachers' intentions or to determine how teachers' behaviors are perceived.

\section{Acknowledgements}

This study was conducted in the scope of the Scientific Research Project Department of Akdeniz University with 
the project number 2014.01.0154.003.

\section{References}

Aiken, L. R., Jr. (1976). Update on attitudes and other affective variables in learning mathematics. Review of Educational Research, 46, 293-311. https://doi.org/10.3102/00346543046002293

Altun, M. (1995). Illkokul 3, 4 ve 5. sını öğrencilerinin problem çözme davranışları üzerine bir çalı̧̧ma. Yayınlanmamış doktora tezi, Hacettepe Üniversitesi Sosyal Bilimler Enstitüsü, Ankara.

Altun, M. (2005). Eğitim fakülteleri ve ilköğretim öğretmenleri için: matematik öğretimi. Bursa: Alfa Yayıncılık.

Arıkan, G. (2004). Kırş̧ehir ilköğretim II. kademe öğrencilerinin matematik kaygı düzeyleri ile matematik başarıları arasındaki ilişski, Yayımlanmamış yüksek lisans tezi. Gazi Üniversitesi. Eğitim Bilimleri Enstitüsü. Ankara.

Aşkar, P. (1986). Matematik dersine yönelik tutumu ölçen likert-tipi bir ölçeğin geliştirilmesi. Eğitim ve Bilim, 11(62), 31-36.

Aydın, B. (2011). İlköğretim ikinci kademe düzeyinde matematik kaygısının cinsiyete göre farklılıkları üzerine bir çalışma. Kastamonu Ĕ̆itim Dergisi, 19(3), 1029-1036.

Baykul, Y. (1990). Illkokul beşinci sinıftan lise ve dengi okulların son sinfflarına kadar matematik ve fen derslerine karşı tutumda görülen değişmeler ve ögrrenci seçme sinavındaki başarı ile ilişskili olduğu düşünülen bazı faktörler. Ankara, ÖSYM Yayınları.

Betz, N. E. (1978). Prevalence, distribution, and correlates of math anxiety in college students. Journal of Counseling Psychology, 25, 441-448. https://doi.org/10.1037/0022-0167.25.5.441

Bindak, R. (2005). İlköğretim öğrencileri için matematik kaygı ölçeği, F.Ü. Fen ve Mühendislik Bilimleri Dergisi, 17(2), 442-448.

Birgin, O., Baloğlu, M., Çatlığlu, H., \& Gürbüz, R. (2010). An investigation of mathematics anxiety among sixth through eighth grade students in turkey. Learning and Individual Differences, 20(6), 654-658. https://doi.org/10.1016/j.lindif.2010.04.006

Bursal, M., \& Paznokas, L. (2006). Mathematics anxiety and pre-service elementary teachers' confidence to teach mathematics and science. School Science and Mathematics, 106(4), 173-179. https://doi.org/10.1111/j.1949-8594.2006.tb18073.x

Campbell, K., \& Evans, C. (1997). Gender issues in the classroom: a comparison of math anxiety. Education, $117(3), 332-339$.

Çelik, H. C., \& Bindak, R. (2005). Sınıf öğretmenliği bölümü öğrencilerinin matematiğe yönelik tutumlarının çeşitli değişkenlere göre incelenmesi. Kastamonu Eğitim Dergisi, 13(2), 427-436.

Dede, Y., \& Dursun, Ş. (2008). İlköğretim II. kademe öğrencilerinin matematik kaygı düzeylerinin incelenmesi. Uludağ Üniversitesi Ĕgitim Fakültesi Dergisi, 21(2), 295-312

Dursun, Ş., \& Bindak, R. (2011). İlköğretim II. kademe öğrencilerinin matematik kaygılarının incelenmesi. Cumhuriyet Üniversitesi Sosyal Bilimler Dergisi, 35(1), 1821.

Ekizoğlu, N., \& Tezer, M. (2007). İlköğretim öğrencilerinin matematik dersine yönelik tutumları ile Matematik başarı puanları arasındaki ilişki. Cypriot Journal of Educational Sciences, 2(1).

Frank, M. L. (1990). What myths about mathematics are held and conveyed by teachers? Arithmetic Teacher, 37(5), 10-12.

Gierl, M., \& Bisanz, J. (1995). Anxieties and attitudes related to mathematics in grades 3 and 6. Journal of Experimental Education, 63(2), 139-159. https://doi.org/10.1080/00220973.1995.9943818

Güvenç, E., \& Güvenç, H. (2014). İlköğretim Matematik ile fen ve teknoloji öğretmenlerinin sınıf yönetim biçemleri ve özerklik desteği algıları. NWSA-Education Sciences, 9(3), 311-322. https://doi.org/10.12739/NWSA.2014.9.3.1C0620

Haynes, A., Mullins, A., \& Stein, B. (2004). Differential models for math anxiety in male and female college students. Social Spectrum, 24(3), 295-318. https://doi.org/10.1080/02732170490431304

Karasar N. (2009). Bilimsel araştırma yöntemleri. Nobel yayınları, Ankara.

Karimi, A., \& Vanketesan, S. (2009). Mathematics anxiety, mathematics performance and academic hardiness in high school students. International Journal of Science Education, 1(1), 33-37. 
https://doi.org/10.1080/09751122.2009.11889973

Katranc1, Y. (2009). Cinsiyet, yaşam standardı ve matematik başarısı ile matematiği yönelik tutum arasındaki ilişki. XVIII. Ulusal Eğitim Bilimleri Kurultayı, Ege Üniversitesi, İzmir.

Khatoon, T., \& Mahmood, S. (2010). Mathematics anxiety among secondary school students in india and its relationship to achievement in mathematics. European Journal of Social Sciences, 16(1), 75-86.

Kumar, V., \& Karimi, A. (2010). Mathematics anxiety, mathematics performance and overall academic performance in high school students. Journal of the Indian Academy of Applied Psychology, 36(1), 147-150.

Lee, V. E. (1996). The influence of school climate on gender differences in the achievement and engagement of young adolescents (Report No. PS 025 154). Washington, DC.

Lussier, G. (1996). Sex and Mathematicsal backround as a predictors of anxiety self efficacy in Mathematics. Psychological Reports, 79, 827-833. https://doi.org/10.2466/pr0.1996.79.3.827

Ma, X. (1999). A Meta-analysis of the relationship between anxiety and toward mathematics and achievement in Mathematics. Journal for Research in Mathematics Education, 30, 502-540. https://doi.org/10.2307/749772

Ma, X., \& Xu, J. (2004). The causal ordering of mathematics anxiety and mathematics achievement: A longitudinal panel analysis. Journal of Adolescence, 27, 165-179. https://doi.org/10.1016/j.adolescence.2003.11.003

McGraw, R., Lubienski, S., \& Strutchens, M. E. (2006). A closer look at gender in NAEP Mathematics achievement and affect data: Intersections with achievement, race/ethnicity, and socio economic status. Journal for Research in Mathematics Education, 37(2), 129-150

McLeod, D. (1988). Affective issues in mathematicsal problem solving: Some theoretical considerations. Journal for Research in Mathematics Education, 19, 134-141. https://doi.org/10.2307/749407

Oğuz A. (2013). Öğretmenlerin öğrenen özerkliğinin desteklenmesine ilişkin görüşleri. Uluslararası İnsan Bilimleri Dergisi, 10(1), 1273-1297.

Oğuz, A.(2012). Öğrenen özerkliğini destekleme ölçeğinin geliştirilmesi. II. Ulusal eğitim programları ve öğretim kongresi, Yayımlanmamış bildiri, 27-29 Eylül 2012, Bolu.

Özkal N. \& Demirkol A. (2014). Öğrenen özerkliğinin desteklenmesinin gerekliliğine ve sergilen-mesine 1lişkin öğretmen görüşleri. NWSA-Education Sciences, 9(3), 293-310. DOI: 0.12739/NWSA.2014.9.3.1C0619.

Peker, M., \& Mirasyedioğlu, Ş. (2003). Lise 2. sınıf öğrencilerinin matematik dersine yönelik tutumları ve başarıları arasındaki ilişki. Pamukkale Üniversitesi Ĕgitim Fakültesi Dergisi, 2(14).

Reys, R. (1995). Helping children learn mathematics. Boston: Allyn \& Bacon.

Şentürk, B. (2010). İlköğretim beşinci sını öğrencilerinin genel başarıları, Matematik başarıları, Matematik dersine yönelik tutumları ve matematik kaygıları arasındaki ilişki. Yayınlanmamış yüksek lisans tezi, Afyon Kocatepe Üniversitesi Sosyal Bilimler Enstitüsü.

Skinner, E. A., Furrer, C., Marchand, G., \& Kindermann, T. (2008). Engagement and disaffection in the classroom: Part of a larger motivational dynamic? Journal of Educational Psychology, 100, 765-781. https://doi.org/10.1037/a0012840

Sloan, T., Daane, C., \& Giesen, J. (2002). Mathematics anxiety and learning styles: What is the relationship in elementary pre-service teachers? School and Science Mathematics, 102(2), 84-87. https://doi.org/10.1111/j.1949-8594.2002.tb17897.x

Tapia, M., \& Marsh, G. E. (2000). Effect of gender, achievement in mathematics, and ethnicity on attitudes toward mathematics. Annual Meeting of the Mid-South Educational Research Association, Bowling Green, KY, USA.

Taş, Y. (2009). Sınav kaygısıyla başa çıkma, kaygı nedir? Bilkent Üniversitesi öğrenci gelişim ve danışma merkezi Bilkent Ankara. TSA, 17(2), 49-68.

Taşdemir, C. (2009). İlköğretim ikinci kademe öğrencilerinin matematik dersine karşı tutumları: Bitlis ili örneği. Dicle Üniversitesi Ziya Gökalp Eğitim Fakültesi Dergisi, 12, 89-96.

Thomas, P., \& Higbee, J. (1999). Affective and cognitive factors related to mathematics achievement. Journal of Developmental Education, 23(1), 8-16.

Tobias, S. (1993). Overcoming math anxiety. New York: W. W. Norton \& Company. 
Üldaş, Ü. (2005). Öğretmen ve öğretmen adaylarına yönelik matematik kaygı ölçeğinin geliştirilmesi ve matematik kaygısına ilişskin bir değerlendirme. Yayımlanmamış yüksek lisans tezi, Marmara Üniversitesi, İstanbul.

Ursini, S., \& Sanchez, E. G. (2008). Gender, technology and attitude towards mathematics. Mathematics Education, 40(5), 559-577.

Vinson, B. (2001). A comparison of pre-service teachers mathematics anxiety before and after a methods class emphasizing manipulatives. Early Childhoood Education Journal, 29(2), 89-94. https://doi.org/10.1023/A:1012568711257

Yenilmez, K., \& Özabacı, N. (2003). Yatılı öğretmen okulu öğrencilerinin matematik ile ilgili tutumları ve Matematik kaygı düzeyleri arasındaki ilişki üzerine bir araştırma. Pamukkale Üniversitesi Eğitim Fakültesi Dergisi, 14(2), 132-146.

Yenilmez, K., \& Özbey, N. (2006). Özel okul ve devlet okulu öğrencilerinin matematik kaygı düzeyleri üzerine bir araştırma [Elektronik versiyon]. Uludağ Üniversitesi Eğitim Fakültesi Dergisi, XIX(2), 431-448.

Yıldırım, İ., \& Ergene, T. (2003). Lise son sınıf öğrencilerinin akademik başarılarının yordayıcısı olarak sınav kaygısı, boyun eğici davranışlar ve sosyal destek. Hacettepe Üniversitesi Eğitim Fakültesi Dergisi, 25, 224-234. https://doi.org/10.1080/08886504.2000.10782293

Yıldırım, S. (2000). Effects of an educational computing course on preservice and inservice teachers: A discussion and analysis of attitudes and use. Journal of Research on Computing in Education, 32(4), 479-495.

Yücel , Z., \& Koç, M. (2011). İlköğretim öğrencilerinin matematik dersine karşı tutumlarının başarı düzeylerini yordama gücü ile cinsiyet arasındaki ilişki. Illköğretim Online, 10(1), 133-143.

Yücel C., Karadağ E. \& Turan S. (2013). TIMSS 2011 Ulusal ön değerlendirme raporu. Eskişehir Osmangazi Üniversitesi Eğitim Fakültesi Eğitimde Politika Analizi Raporlar Serisi I.

Zettle, R., \& Raines, S. (2000). The relationship of trait and test anxiety with mathematics anxiety. College Student Journal, 34, 246-258.

\section{Copyrights}

Copyright for this article is retained by the author(s), with first publication rights granted to the journal.

This is an open-access article distributed under the terms and conditions of the Creative Commons Attribution license (http://creativecommons.org/licenses/by/4.0/). 